Vol. 1 No. 2 September 2021 e-ISSN : 2797-3344 P-ISSN : 2797-3336

\title{
PENINGKATAN HASIL BELAJAR MATEMATIKA MATERI PERSAMAAN GARIS LURUS MELALUI APLIKASI GOOGLE CLASSROOM
}

\author{
SRI TUGIYATMI \\ SMP Negeri 225 Jakarta \\ e-mail: sri.tugiyatmi@gmail.com
}

\begin{abstract}
ABSTRAK
Penelitian ini bertujuan untuk meningkatkan hasil belajar matematika peserta didik kelas VIII.A SMP Negeri 225 Jakarta yang berjumlah 40 peserta didik, melalui penerapan aplikasi google classroom. Penelitian dilaksanakan pada semester ganjil Tahun Pelajaran 2021- 2022 tepatnya bulan September sampai datang bulan Desember 2021. Metode penelitian yang digunakan adalah peneltian tindakan kelas yang dirancang dalam dua siklus. Setiap siklus dilaksanakan dalam empat tahapan yaitu perencanaan, pelaksanaan, evaluasi dan refleksi. Hasil penelitian didapatkan data hasil belajar peserta didik pada Pra Siklus, nilai rata- rata peserta didik hanya 63,25 . Peserta didik yang mencapai ketuntasan yaitu peserta didik yang memperoleh nilai sama dengan atau diatas KKM ( KKM=75) sebanyak 10 peserta didik $(25,00 \%)$. Pada Siklus I , nilai rata- rata peserta didik sebesar 72,00. Peserta didik yang mencapai ketuntasan sebanyak 25 peserta didik $(62,50 \%)$. Pada Siklus II , peserta didik yang mencapai ketuntasanswebanyak 31 peserta didik $(77,50 \%)$. Hasil penelitian ini menunjukkan bahwa terjadi peningkatan hasil belajar matematika sebesar $15 \%$. Kesimpulan penelitian ini adalah pembelajaran melalui penerapan aplikasi google classroom dapat meningkatkan hasil belajar matematika pada peseta didik kelas VIII.A di SMP Negeri 225 Jakarta.
\end{abstract}

Kata Kunci: matematika, google classroom, hasil belajar

ABSTRACT

This study aims to improve the mathematics learning outcomes of class VIII.A students at SMP Negeri 225 Jakarta, totaling 40 students, through the application of the Google Classroom application. The research was carried out in the odd semester of the 2021-2022 Academic Year, precisely from September to December 2021. The research method used was classroom action research which was designed in two cycles. Each cycle is carried out in four stages, namely planning, implementation, evaluation and reflection. The results of the study obtained data on student learning outcomes in the Pre-Cycle, the average value of students was only 63.25. Students who achieve completeness are students who get a score equal to or above the KKM $(\mathrm{KKM}=75)$ as many as 10 students $(25.00 \%)$. In Cycle $\mathrm{I}$, the average value of students is 72.00. There were 25 students $(62.50 \%)$ who achieved completeness. In Cycle II, students who achieved completeness were 31 students $(77.50 \%)$. The results of this study indicate that there is an increase in mathematics learning outcomes by $15 \%$. The conclusion of this study is that learning through the application of the Google Classroom application can improve mathematics learning outcomes for class VIII.A students at SMP Negeri 225 Jakarta.

Keywords: mathematics, google classroom, learning outcomes

\section{PENDAHULUAN}

Matematika merupakan ilmu dasar yang mempunyai peranan penting dalam perkembangan ilmu pengetahuan dan teknologi . Banyak peserta didik di sekolah memandang matematika sebagai mata pelajaran yang paling sulit. Padahal matematika merupakan salah satu mata pelajaran yang sangat berguna dalam kehidupan sehari-hari . Pada kenyataannya hasil belajar peserta didik masih rendah.Hasil belajar adalah kemampuan yang dimiliki peserta didik setelah ia menerima pengalaman belajarnya. Setelah suatu proses belajar berakhir, maka peserta didik memperoleh suatu hasil belajar. Hasil belajar mempunyai peranan penting dalam proses pembelajaran. Tujuan utama yang ingin dicapai dalam kegiatan pembelajaran adalah hasil 


\section{Vol. 1 No. 2 September 2021 e-ISSN : 2797-3344 P-ISSN : 2797-3336}

belajar. Hasil belajar digunakan untuk mengetahui sebatas mana peserta didik dapat memahami serta mengerti materi tersebut.

Menurut Hamalik (2004: 31) hasil belajar adalah pola-pola perbuatan, nilai-nilai, pengetahuanpengetahuan, sikap-sikap, apresiasi, abilitas, dan keterampilan. Dalam pembelajaran saat ini, guru matematika masih menerapkan pembelajaran jarak jauh melalui WA dan Grub Kelas. Cara ini kurang menarik . Berdampak pada motivasi peserta didik rendah, peserta didik kurang memiliki keberanian untuk bertanya apalagi mengemukakan pendapat. Hal demikian pada akhirnya mengakibatkan hasil belajar peserta didik rendah.

Dalam pembelajaran matematika banyak metode mengajar yang dapat digunakan, namun tidak setiap metode mengajar cocok dengan materi pokok bahasan yang diajarkan. Berbagai media dan metode yang dipakai oleh guru seperti metode ceramah, penggunaan power point, diskusi dan tanya jawab rupaya masih kurang dalam memfasilitasi peserta didik untuk belajar lebih serius khususnya belajar matematika. Perkembangan teknologi informasi dan komunikasi di era industri telah memiliki pengaruh besar terhadap proses pembelajaran. Menurut Keengwe \& Georgina (2012) dalam penelitiannya menyatakan bahwa perkembangan teknologi memberikan perubahan terhadap proses pengajaran dan pembelajaran. Internet yang semakin luas dan canggih sebagai alat sarana untuk mempermudah pembelajaran. Pembelajaran berbasis daring (online) dibutuhkan sebagai sarana atau alat untuk pendukung proses pembelajaran saat ini. Salah satu media teknologi yang sering digunakan saat ini adalah aplikasi pada telepon genggam. Hasil penelitian Gheytasi et al., (2015) menunjukan bahwa peserta didik yang banyak berinteraksi dengan telepon genggam lebih mudah memahami isi teks bacaan. Banyak berbagai macam media pembelajaran yang ada namun belum digunakan guru secara maksimal. Salah satunya adalah penggunaan media aplikasi google classroom dapat dimanfaatkan sebagai media pembelajaran untuk membantu meningkatkan hasil belajar peserta didik. Desain dari google classroom sudah tidak asing lagi bagi peserta didik karena mereka sudah menggunakan beberapa produk dari google via akun google Apps (Izenstark dan Leahy, 2015). Penggunaan google classroom ini sesungguhnya mempermudah guru dalam mengelola pembelajaran dan menyampaikan informasi secara cepat dan akurat kepada peserta didik (Hardiyana, 2015). Google classroom di desain untuk empat pengguna yaitu pengajar, peserta didik, wali dan administrator. Kelebihan aplikasi google classroom dibandingan dengan aplikasi lain yaitu aplikasi google classroom dapat digunakan untuk membuat dan mengelola kelas, tugas, nilai serta memberikan masukan secara langsung. Peserta didik dapat memantau materi dan tugas kelas, berbagi materi dan berinteraksi dalam kelas atau melalui email, mengirim tugas dan mendapatkan masukan nilai secara langsung. Pembelajaran dengan penggunaan google classroom ini memiliki kelebihan untuk mempermudah peserta didik dalam belajar. Berdasarkan jurnal penelitian Rozak dan Albantani (2018) yang berjudul "Desain Perkuliahan Bahasa Arab Melalui Google Classroom" menyimpulkan bahwa dalam proses pembelajaran Bahasa Arab melalui google classroom memberikan kemudahan bagi mahasiswa dan dosen dalam proses perkuliahan karena adanya jalinan komunikasi secara langsung dan jelas, terutama komunikasi tugas mengenai tugas dan materi yang disampaikan. Dengan adanya aplikasi google classroom ini diharapkan mempermudah peserta didik untuk belajar sehingga dapat meningkatkan hasil belajarnya. Dari hasil wawancara dengan guru mata pelajaran matematika selama ini proses pembelajaran belum menggunakan teknologi yang bisa membantu proses pembelajaran, contohnya dengan pembelajaran berbasis daring. Padahal dengan penggunaan media pembelajaran berbasis daring inilah dapat mempermudah guru dalam kegiatan pembelajaran dan mempermudah peserta didik dalam belajar. Oleh karena itu, penelitian ini telah menyajikan metode pembelajaran berbasis daring yaitu penggunaan aplikasi google classroom untuk membantu disetiap proses peembelajaran. Hal ini disebabkan karena hampir semua peserta didik memiliki telepon genggam untuk mengakses aplikasi google classroom. Google classromm adalah aplikasi yang dikembangkan oleh perusahaan google. Dengan adanya aplikasi ini pengajar dan peserta didik dari sekolah manapun bisa berkomunikasi dengan cara yang jauh lebih sederhana. Salah satu kekuatan google classroom yaitu memungkinkan 


\section{Vol. 1 No. 2 September 2021 e-ISSN : 2797-3344 P-ISSN : 2797-3336}

penghematan kertas karena pekerjaan atau dokumen yang digunakan di kelas akan dibagikan secara digital. selain mudah digunakan di aplikasi google classroom ini menyajikan berbagai macam fitur yang mendukung pada proses kegiatan pembelajaran, seperti membuat salinan dokumen otomatis untuk peserta didik, membuat tugas dan langsung menilainya. Kelebihan aplikasi google classroom dibandingkan dengan aplikasi yang lain yaitu aplikasi google classroom ini bisa diakses secara gratis dan dirancang khusus untuk membantu guru atau pengajar dalam pembelajaran.

SMP Negeri 225 Jakarta yang letaknya di Jl Warung Gantung Kp. Kojan Kalideres mempunyai 24 kelas, yaitu kelas VII terdiri 8 kelas, kelas VIII terdiri 8 kelas dan kelas IX terdiri 8 kelas. Berdasarkan laporan Panitia PTS Ganjil Th. 2021- 2022 nilai rata- rata 69. Nilai ini masih di bawah KKM yaitu 75. Dari uraian diatas maka penelitian ini sangat penting dilakukan untuk meningkatkan hasil belajar peserta didik.

\section{METODE PENELITIAN}

Jenis penelitian ini adalah penelitian tindakan kelas (PTK) bertujuan untuk melakukan perbaikan- perbaikan terhadap sistem, cara kerja, proses, isi dan kompetensi atau situasi pembelajaran di kelas.

Penelitian ini dilaksanakan di SMP Negeri 225 Jakarta yang berada di Jl. Warung Gantung Kp. Kojan Kalideres Telp.5409941. Subyek penelitian adalah peserta didik kelas VIII.A SMP Negeri 225 Jakarta Th. Pelajaran 2021- 2022 yang terdiri 40 peserta didik , 22 siswa laki- laki dan 18 siswa perempuan, seorang guru matematika dan seorang observer. Penelitian ini dilaksanakan pada bulan Oktober sampai dengan bulan Desember 2021 .

Prosedur Penelitian yang digunakan adalah jenis penelitian tindakan kelas (PTK) model Stephen Kemmis dan Robin MC Taggart yang meliputi siklus- siklus yang mencakup 4 tahap terdiri dari Perencanaan ( Planning), Tindakan ( Action), Observasi (Observation) dan Refleksi (Reflection).

Berikut ini adalah gambar rancangan penelitian tindakan kelas menurut Stephen Kemmis dan Mc. Taggart (1998) terlihat pada gambar 1 di bawah ini.



Gambar 1. Rancangan penelitian tindakan kelas

Langkah- langkah tindakan adalah sebagai berikut : Penelitian ini dilaksanakan 2 siklus, masing- masing siklus mencakup empat tahap yaitu perencanaan , pelaksanaan tindakan, observasi dan refleksi. Masing - masing siklus terdiri 3 pertemuan.. Prosedur pengumpulan data dalam penelitian ini adalah sebagai berikut : a). Data hasil belajar diambil dari tes evaluasi.. b).Data tentang proses belajar pada saat pelaksanaan tindakan diambil dengan lembar observasi. 


\section{Vol. 1 No. 2 September 2021 e-ISSN : 2797-3344 P-ISSN : 2797-3336}

Alat pengumpul data dalam penelitian ini adalah sebagai berikut : a). Tes Tertulis (online).b). Lembar observasi yang terdiri dari lembar observasi untuk guru dan peserta didik . Pada penelitian ini menggunakan análisis deskriptif yaitu metode penelitian yang menggambarkan kenyataan, fakta, sesuai dengan data yang diperoleh. Tujuannya untuk mengetahui hasil belajar yang dicapai peserta didik, juga untuk memperoleh respon peserta didik terhadap kegiatan pembelajaran. Untuk memperoleh tingkat dengan menggunakan nilai rata- rata hasil tes atau prosentase.

\section{HASIL DAN PEMBAHASAN}

\section{Hasil Penelitian Tindakan}

\section{Siklus Pertama}

Hasil belajar peserta didik pada siklus pertama diperoleh setelah peserta didik melakukan evalusai yang dilakukan pada pertemuan ketiga pada hari Kamis , 4 Nopember 2021.Nilai yang diperoleh dengan rata-rata 72 sedangkan jumlah peserta didik yang sudah tuntas adalah 25 atau mencapai $62,5 \%$ dan jumlah siswa yang belum tuntas mencapai 15 orang atau $37,5 \%$. Ini berarti belum memenuhi indikator yang telah ditentukan, maka perlu diadakan penelitian pada siklus kedua.

Tabel 1 Perolehan Nilai Tes Siklus Pertama

\begin{tabular}{|c|c|c|c|}
\hline NOMOR & NILAI & FREKUENSI & RATA- RATA \\
\hline 1 & $0-19$ & 0 & \\
\hline 2 & $20-39$ & 1 & \multirow{2}{*}{72,00} \\
\hline 3 & $40-59$ & 8 & \\
\hline 4 & $60-79$ & 6 & \\
\hline 5 & $80-100$ & 25 & \\
\hline \multicolumn{2}{|c|}{ Jumlah } & 40 & \\
\hline
\end{tabular}

Berdasarkan pada tabel 1 di atas, dapat diketahui bahwa hasil belajar peserta didik kelas VIII.A yang mengikuti pembelajaran dengan penerapan aplikasi google classroom diperoleh nilai rata-rata hasil belajar matematika sebesar 72,00 dan ketuntasan belajar 62,50\% atau ada 25 peserta didik dari 40 peserta didik sudah tuntas belajar. Hasil ini menunjukkan bahwa secara klasikal peserta didik belum tuntas belajar, karena peserta didik yang memperoleh nilai $\geq 75$ (KKM) hanya sebesar $62,50 \%$ lebih kecil dari prosentase ketuntasan yang dikehendaki yaitu sebesar $75 \%$.

Berdasarkan hasil refleksi siklus pertama (siklus I) diketahui bahwa tidak tercapainya ketuntasan aktivitas belajar peserta didik dipengaruhi oleh beberapa hal yaitu: 1) anak belum terbiasa menggunakan google classroom, 2) masih terdapat peserta didik yang pasif mengikuti pembelajaran seperti terbatasnya kuota internet peserta didik atau terkendala jaringan bahkan ada yang masih malas untuk membuka classroom. Oleh karena itu peneliti merasa perlu melakukan perbaikan tindakan terhadap proses pembelajaran yang telah dilakukan pada siklus pertama (siklus I) dengan lebih mendekatkan diri kepada peserta didik dengan cara videocall, di samping itu guru membantu peserta didik secara intensif terutama peserta didik yang pasif.

\section{Siklus Kedua}

Hasil belajar peserta didik pada siklus kedua diperoleh setelah peserta didik melakukan evaluasi yang dilakukan pada pertemuan ketiga pada hari Kamis tanggal 25 Nopember 2021. Nilai yang diperoleh dengan rata-rata 79, sedangkan peserta didik yang tuntas sebanyak 31 peserta didik atau 77,5\% naik $24 \%$ dari ketuntasan belajar pada siklus pertama dan jumlah peserta didik yang belum tuntas 9 peserta didik atau mencapai $22,5 \%$.

Dari hasil tersebut disimpulkan bahwa peneliti telah dapat melaksanakan tahap- tahap pembelajaran dengan aplikasi google classroom, sehingga pembelajaran dapat berjalan lancar dan baik...Hal ini dapat dilihat dari hasil rata- rata nilai pada siklus kedua, sudah memenuhi target indikator kerja. 
Tabel 2. Perolehan Nilai Tes Siklus Kedua

\begin{tabular}{|c|c|c|c|}
\hline NOMOR & NILAI & FREKUENSI & RATA- RATA \\
\hline 1 & $0-19$ & 0 & \multirow{2}{*}{79,00} \\
\hline 2 & $20-39$ & 0 & \\
\hline 3 & $40-59$ & 4 & \\
\hline 4 & $60-79$ & 5 & \\
\hline 5 & $80-100$ & 31 & \\
\hline & Jumlah & 40 & \\
\hline
\end{tabular}

Berdasarkan pada tabel 2 di atas, dapat diketahui bahwa hasil belajar peserta didik kelas VIII.A yang mengikuti pembelajaran dengan penerapan aplikasi google classroom diperoleh nilai rata-rata hasil belajar matematika sebesar 79,00 dan ketuntasan belajar 77,50 \% atau ada 31 peserta didik dari 40 peserta didik sudah tuntas belajar. Hasil ini menunjukkan bahwa secara klasikal peserta didik sudah tuntas belajar, dan sudah memenuhi syarat karena jumlah peserta didik yang telah mencapai nilai $\geq 75(\mathrm{KKM})$ sebanyak $77,5 \%$ dan berada diatas kriteria ketuntasan klasikal $75 \%$.

Dari hasil penelitian ditemukan bahwa penerapan aplikasi google classroom dapat meningkatkan hasil belajar siswa. Hal ini dapat dilihat pada tabel 3 atau grafik 1 berikut ini.

Tabel 3. Nilai Rata- rata Hasil Belajar

\begin{tabular}{|c|c|}
\hline TES & NILAI RATA- RATA \\
\hline SIKLUS 1 & 72,00 \\
\hline SIKLUS 2 & 79,00 \\
\hline
\end{tabular}

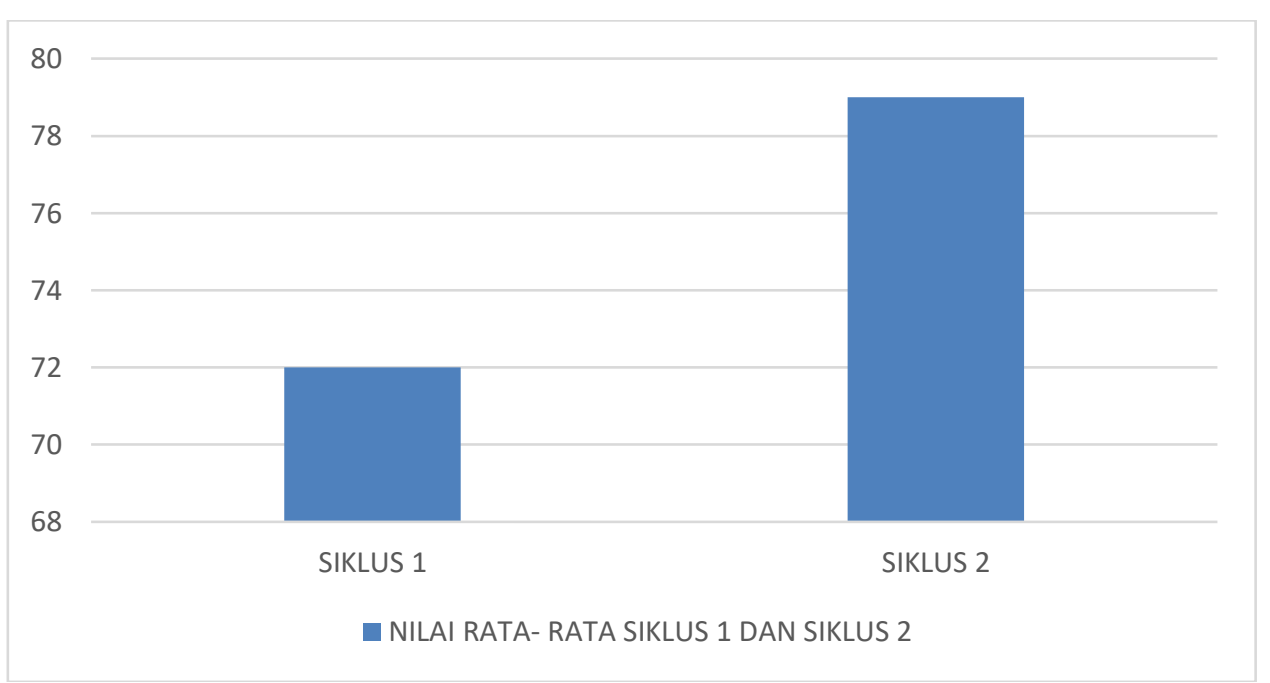

Gambar 1. Grafik Nilai Rata- Rata Siklus 1 dan Siklus 2

Berdasarkan grafik 1, dapat diketahui bahwa hasil belajar peserta didik kelas VIII.A yang mengikuti pembelajaran dengan penerapan aplikasi google classroom mengalami peningkatan dari siklus I ke Siklus 2 sebesar 9,72 \% dari rata-rata 72,00 pada siklus I menjadi 79,00 pada siklus II.

Tabel 4. Prosentase Ketuntasan Hasil Belajar

\begin{tabular}{|c|c|}
\hline SIKLUS & PROSENTASE KETUNTASAN \\
\hline SIKLUS 1 & 62,50 \\
\hline
\end{tabular}


Vol. 1 No. 2 September 2021 e-ISSN : 2797-3344 P-ISSN : 2797-3336

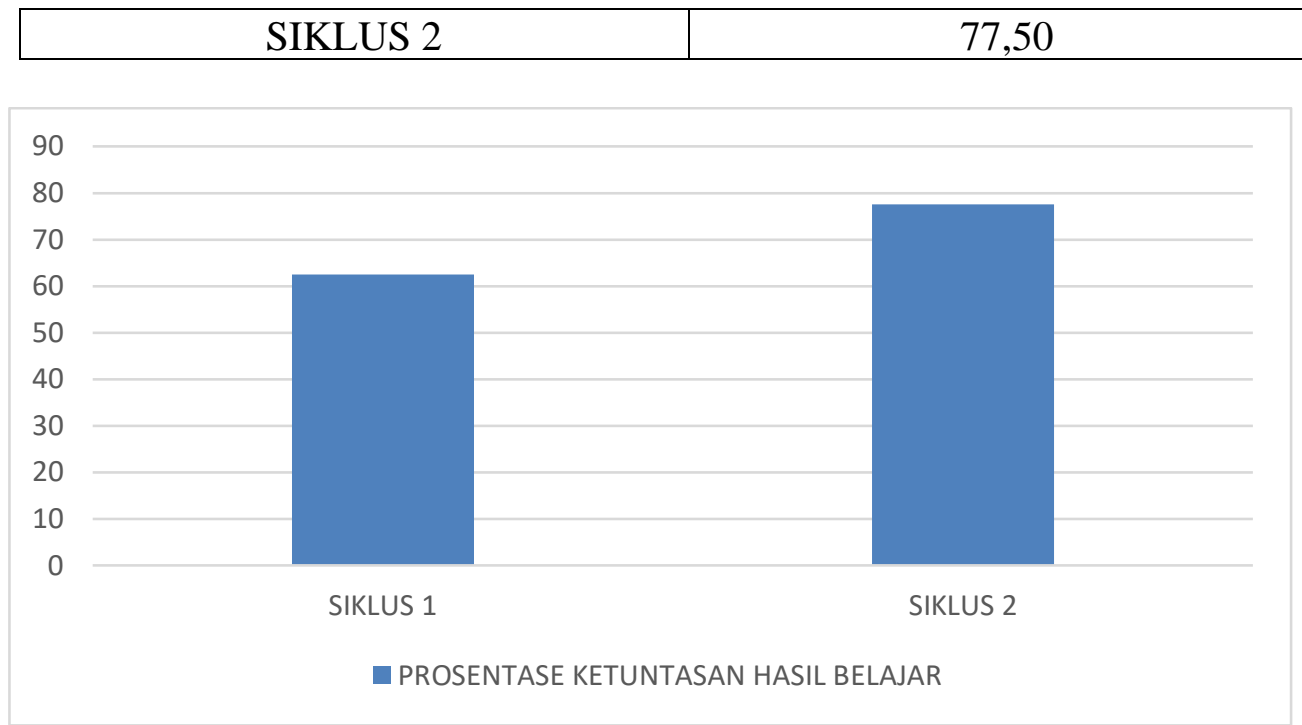

Gambar 2. Grafik Prosentase Ketuntasan Hasil Belajar

Berdasarkan grafik 2 , dapat diketahui bahwa hasil belajar peserta didik kelas VIII.A yang mengikuti pembelajaran dengan penerapan aplikasi google classroom ketuntasan klasikal mengalami peningkatan dari siklus I ke siklus 2 sebesar 15\% dari KK 62,50\% siklus I menjadi KK 77,50\% pada siklus II

Berdasarkan hasil penelitian diatas dapat digambarkan bahwa penerapan aplikasi google classroom dapat meningkatkan hasil belajar peserta didik. Hali ini diperkuat oleh penelitian Ningrum (2020) yang menyatakan bahwa Aplikasi Google Classroom sebagai media interaktif online yang sebagian besar dipergunakan untuk media belajar dan quis untuk peserta didik dapat meningkatkan hasil belajar peserta didik. Dalam teori pembelajaran daring ( Bilfaqih dan Qomarudin, 2015) juga dijelaskan bahwa dalam pembelajaran penting sekali untuk menerapkan pemanfaatan multimedia interaktif yang efektif, untuk meningkatkan hasil belajar peserta didik dan mutu pendidikan.

\section{Pembahasan}

(Bagas P.P \& Harimukti, 2017), menyimpulkan bahwa terdapat perbedaan hasil belajar yang siqnifikan antar kelas eksperimen yang menggunakan pembelajaran dengan google classroom dan kelas yang hanya menggunakan pembelajaran berbasis proyek. Dengan demikian untuk membangkitkan motivasi dan perhatian peserta didik dalam pembelajaran dengan mengubah sikap peserta didik yang semula pasif membuka classroom untuk menjadi aktif dan semangat, ceria dan menyenangkan. (Musfiqon, 2012 : 8), hasil belajar peserta didik dipengaruhi oleh 2 faktor utama yaitu faktor dari dalam diri peserta didk(internal factor) dan faktor yang datang dari luar di ( external factor). Faktor dari dalam diri peserta didik terutama menyangkut kemampuan yang dimiliki siswa. Faktor ini besar sekali pengaruhnya terhadap hasil belajar yang akan dicapai. Berkaitan dengan faktor dari dalam diri peserta didik, selain faktor kemampuan , ada juga faktor lain yaitu motivasi , minat, perhatian, sikap, kebiasaan belajar , ketekunan, kondisi sosial ekonomi, kondisi fisik dan psikis.

Berdasar tabel 4 menunjukkan bahwa hasil tes pemahaman terhadap materi pelajaran pada siklus I hanya mencapai $62,50 \%$ yang memperoleh nilai KKM, yaitu $\geq 75,00$. Ini berarti indikator keberhasilan siswa (penelitian) belum tercapai. Hal ini kemungkinan disebabkan peserta didik masih belum beradaptasi terhadap pembelajaran dengan classroom ini, sehingga masih agak kesulitan dalam memahami materi pelajaran, mereka masih disibukkan dengan asyiknya bermain HP, kurang peduli dengan materi bahkan banyak main game di HP.

Pada siklus II, pencapaian hasil belajar tentang pemahaman terhadap materi pelajaran mengalami peningkatan, yaitu mencapai 77,50\% siswa memperoleh nilai KKM yaitu $\geq 75,00$, yang berarti indikator keberhasilan peserta didik terhadap materi pelajaran bisa tercapai. 
Vol. 1 No. 2 September 2021 e-ISSN : 2797-3344 P-ISSN : 2797-3336

Berdasarkan uraian tersebut, maka dapat dinyatakan bahwa "pembelajaran dengan menggunakan aplikasi google classroom dapat meningkatkan motivasi yang kemudian meningkatkan pula hasil belajar peserta didik kelas VIII.A SMP Negeri 225 Jakarta ”.

\section{KESIMPULAN}

Berdasarkan pengamatan dan analisis data, pada siklus pertama penggunaan aplikasi google classroom dalam pembelajaran masih kurang efektif dan efisien pelaksanaannya, karena siswa masih kurang memahami peraturan dalam penggunaan google classroom, selain itu masih ada yang terkendala kuota jaringan yang kurang baik dan ada yang masih malas . Pada siklus kedua, setelah dilakukan pembimbingan lebih intensif secara individual melaui chat di classroom, pelaksanaan kegiatan belajar mengajar lebih efektif dan efisien, pesetrta didik aktif dan perhatian, pembelajara di classroom lebih menarik dan menyenangkan peserta didik..

Berdasarkan hasil penelitian ini dapat disimpulkan, bahwa penggunaan aplikasi google classroom dalam pembelajaran dapat meningkatkan hasil belajar dan meningkatkan pemahaman peserta didik pada mata pelajaran Matematika di kelas VIII.A SMP Negeri 225 Jakarta.

\section{DAFTAR PUSTAKA}

Bagas Panca Pradana, Diemas dan Riana Harimurti. Pengaruh Penerapan Tools Google Classroom pada Model Pembelajaran Project Based Learning Terhadap Hasil Belajar Siswa. Jurnal IT-Edu Universitas Negeri Surabaya. Vol.02 No.01, 2017

Bilfaqih, Y., \& Qomarudin, M. N. (2015). Esensi Penyusunan Materi Pembelajaran Daring. Yogyakarta: Deepublish.

Gheytasi, M., Azizifar, A., \& Gowhary, H. (2015). The Effect of Smartphone on the Reading Comprehension Proficiency of Iranian EFL Learners. Procedia - Social and Behavioral Science, 199, 225-230.

Hamalik, Oemar, 2004. Proses Belajar Mengajar. Jakarta : PT.Bumi Aksara

Hardiyana, A.(2015) Implementasi Classroom Sebagai Alternatif dalam Meningkatkan Mutu Pembelajaran di Sekolah. Karya Tulis Ilmiah. Cirebon : SMA Negeri 1 Losari

Izenstark, Amanda and Katie L. Leahy. 2015. "Google Classroom for Librarians : Features and Opportunities. ” Library Hi Tech News 32 (9):1-3. https://doi.org/10.1108/LHTN05-2015-0039.

Keengwe, J., \& Georgina, D. (2012). The digital course training workshop for online learning and teaching. Education and Information Technologies, 17(4), 365-379.

Kemmis \& McTaggart. (1998). The Action Research Planner. Victoria Dearcin University Press.

Musfiqon. 2012. Pengembangan Media dan Sumber Pembelajaran. Jakarta: PT Prestasi Pustakaraya.

Ningrum, Anita(2020). Analisis Pelaksanaan Pembelajaran Google Classroom Era Pandemik Covid 19 Materi Tata Surya Pada Siswa Kelas VII MTs. Negeri Salatiga Tahun Pelajaran 2019-2020. Disertasi. Program Sarjana Program Studi Tadris Ilmu Pengetahuan Alam Fakultas Tarbiyah dan Ilmu Keguruan IAIN Salatiga, http://erepository.perpus.iainsalatiga.ac.id/eprint/8565.

Rozak, A., \& Albantani, A. M. (2018). Desain Perkuliahan Bahasa Arab Melalui Google Classroom. Arabiat : Jurnal Pendidikan Bahasa Arab Dan Kebahasaaraba, 5(1), 83102 